\title{
South Florida flatwoods range vegetation responses to season of deferment from grazing
}

\author{
ROB S. KALMBACHER, FRANK G. MARTIN, W.D. PITMAN, AND GEORGE W. \\ TANNER
}

\begin{abstract}
Authors are agronomist, Ona Agricultural Research and Education Center (AREC), Ona, Fla. 33865; professor of statistics, University of Florida, Gainesville 32611; associate agronomist, Ona AREC; and associate professor Dep. Wildlife and Range Science.
\end{abstract}

\begin{abstract}
Wiregrass (Aristida stricta Michx.)-dominated communities characterize extensive areas of South Florida that have been subjected to burning and uncontrolled grazing for decades. We evaluated the effects of deferment from grazing on species composition and herbage mass of these rangelands. Treatments were 1-ha exclosures that were closed to grazing December to March, closed April to July, closed August to November, always closed, or always open. All treatments were burned biennially. Herbage mass of preferred grasses was greater $(P<0.05)$ after 8 years in exclosures that were always closed (avg. $110 \mathrm{~kg} \mathrm{ha}^{-1}$ ) compared with other treatments, which were not different (avg. $65 \mathrm{~kg} \mathrm{ha}^{-1}$ ). Herbage mass of preferred grasses increased by $10 \mathrm{~kg} \mathrm{ha}^{-1}$ year-1 $^{-1}$. Shrub biomass was greater in the treatment that was always closed $\left(2,370 \mathrm{~kg} \mathrm{ha}^{-1}\right)$ compared with other treatments (avg. $1,855 \mathrm{~kg}$ $\mathrm{ha}^{-1}$ ), and biomass increased quadratically over years. There were no effects due to treatments or years on biomass of wiregrass, other less desirable grasses, grasslike species, or forbs. Frequency of occurrence of preferred grasses was not affected by treatment and averaged $41 \%$. Although preferred grasses were relatively abundant, neither their biomass nor frequency of occurrence increased on a scale relevant to management for cattle production when protected from grazing. This biennially burned, seasonally flooded, infertile wiregrass range is not highly responsive to grazing or deferment from grazing, hence responses may not justify the inputs required for more intensive grazing management.
\end{abstract}

Key Words: Florida flatwoods range, wiregrass, Aristida stricta, range improvement, species composition

Cutover pinelands in south Florida, referred to as flatwoods range, are dominated today by herbaceous and shrubby vegetation with or without a scattered overstory of trees. Environmental factors such as soil type, hydroperiod, and fire provide such stability to these communities that White (1973) suggested they be considered climax unless environmental restraints are altered. Due to rapid plant maturity resulting in extremely low forage quality, controlled burning has been widely recommended and used in flatwoods range management (Kirk and Hodges 1970, Hughes 1974, Lewis et al. 1982).

Productive, relatively palatable grasses such as creeping and chalky bluestems (Table 1), indiangrass and little blue maidencane have been considered preferred range grasses (SCS 1987). Other less productive and less palatable grasses, such as Aristida spp., are often considered less desirable. Grazing systems have been advo-

\footnotetext{
The authors wish to thank Mr. Bayard Toussaint, former general manager, Crescent B Ranch, for help in carrying out the study; Mr. Howard Yamataki, USDA, SCS soil scientist, for on-site soil classification; and $\mathrm{Mr}$. William Shilling, Florida Division of Forestry, for tree site index determinations.

University of Florida Journal Series R-02953.

Manuscript accepted 18 Jun. 1993.
}

cated as a means to change the proportions of preferred and less-desirable grasses. Changing the composition of wiregrassdominated range simply by deferring grazing in a particular season has not been demonstrated. From a 14-year study on frequently burned South Florida range, Hughes (1974) found that production from a cow-calf herd was inversely related to stocking rate, and that the lowest stocking rate resulted in decreases in wiregrass and increases in the more palatable bluestems and Panicum spp. From these results, Hughes suggested that deferment from grazing following utilization of spring regrowth (after burning) should "encourage a natural increase of the better grasses." Prevatt et al. (1985) assumed that rotational grazing would result in an annual before-tax net return of $\$ 0.17 \mathrm{ha}^{-1}$ based on an increase of $280 \mathrm{~kg}$ $\mathrm{ha}^{-1}$ of grazeable dry matter with a 10-year life of improvement (fences). If changes in species composition resulting in greater production of palatable forage do not occur, rotational grazing could result in an economic loss to cattlemen.

The purpose of this investigation was to measure the changes in herbage mass and botanical composition as affected by season of rest on flatwoods range that had been historically managed for cattle production by burning and continuous grazing. Our hypothesis was that production and occurrence of preferred grasses (i.e., range condition) would improve when range was protected from grazing in the appropriate season.

\section{Methods and Materials}

Research was conducted on the Boyd's Bay unit of the Cresent B ranch in Charlotte County, Fla. Boyd's Bay is about 4,400 ha of flatwoods range with no cross fences and had been grazed since the 1930s when pines were harvested. Controlled burning had been the only range management tool used in the past 50 years. Portions (2 to $3 \mathrm{~km}^{2}$ ) of the range were burned November to March and about 300 head of cattle concentrated grazing on recently burned areas.

Twenty, 1-ha $(100$ by $100 \mathrm{~m}$ ) barbed wire exclosures with $6-\mathrm{m}$ gates on diagonal corners were built in the center of Boyd's Bay during fall 1981 and winter 1982 . Their location was not random, as areas were selected that appeared similar from exclosure to exclosure. Ten exclosures (replicates I and II) were scattered over 100 ha of Myakka fine sand (sandy, siliceous, hyperthermic Aeric Haplaquods) with some Immokalee (sandy, siliceous, hyperthermic Arenic Haplaquods) and Punta (sandy, siliceous, hyperthermic Grossarenic Haplaquods) soils. The other 10 exclosures (replicates III and IV) were grouped about $1 \mathrm{~km}$ from replicates I and II and were also scattered over about 100 ha. Soils were mostly Immokalee fine sand with some Smyrna (sandy, siliceous, hyperthermic Aeric Haplaquods), Bassinger (siliceous, hyperthermic Spodic Psammaquents) and Myakka soils. Climate, topography, and vegetation have been described for the Caloosa Experimental 
Table 1. Scientific and common names of plants found within exclosures on Boyd's Bay 1982 to 1990.

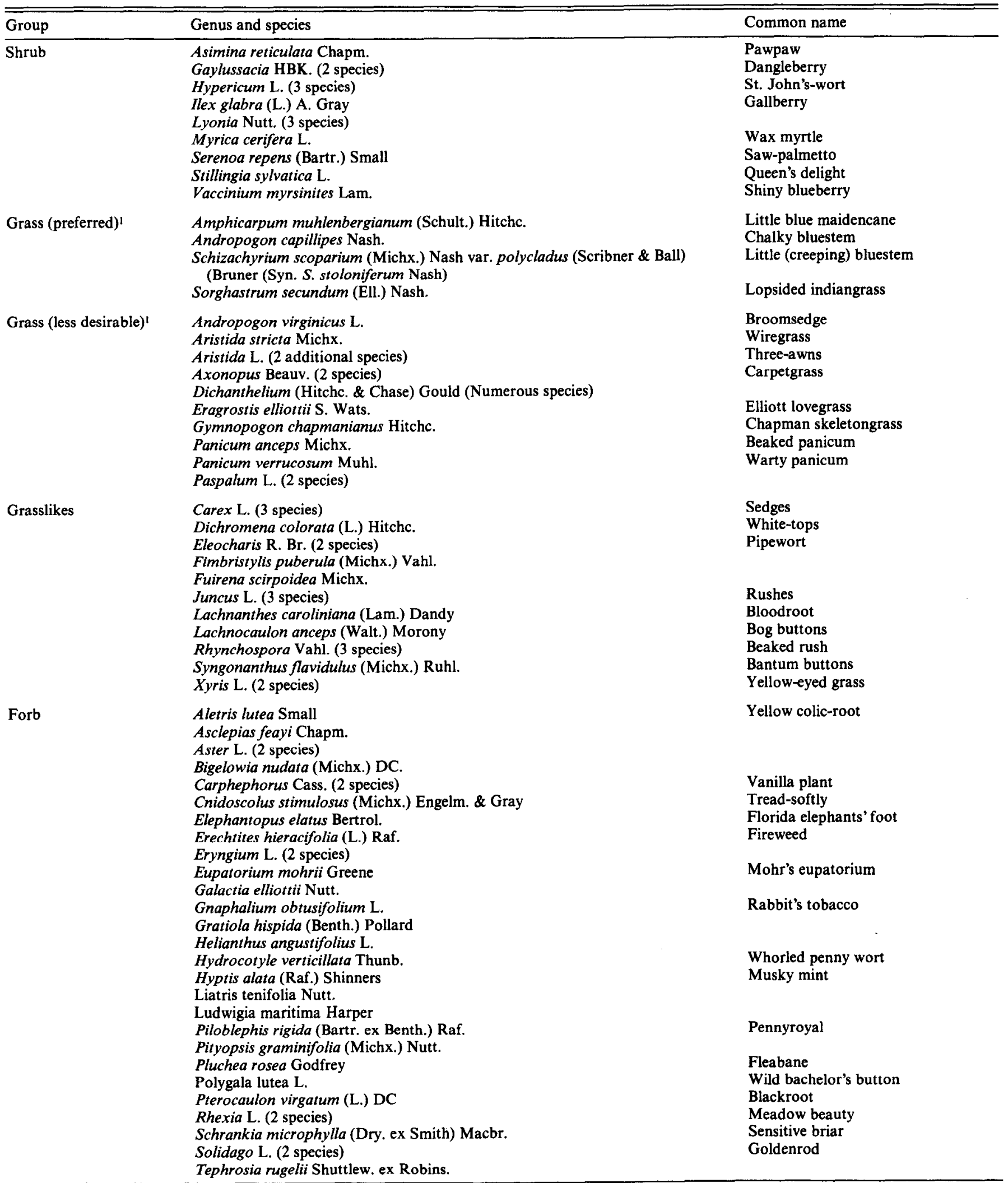

'Classified as decreaser and increaser grasses according to USDA, SCS (1987). 
Range, which is similar to and about $30 \mathrm{~km}$ southwest of Boyd's Bay (Hilmon 1964). Like Boyd's Bay, the history of the Caloosa range is known to be one of frequent burning and grazing.

Two, 120-m permanent transects were established on the diagonals in each exclosure. Twenty-five, $0.25-\mathrm{m}^{2}(0.5$ by $0.5-\mathrm{m})$ quadrats were examined on each transect. Presence or absence of all plants growing in the $\mathbf{5 0}$ quadrats in each exclosure were listed, and herbage from the following groups of plants was cut at the soil surface and weighed: shrubs; preferred grasses; wiregrass, which was the major less desirable grass; other less desirable grasses; and forbs (Table 1). Grasslike species were combined with other less desirable grasses because of the time required to separate these 2 components. All vegetation was weighed if it was included within imaginary vertical planes extending up from the quadrat frame. Fresh plant weights obtained in the field were converted to dry matter on the basis of samples dried at $60^{\circ} \mathrm{C}$ for 72 hours. Exclosures were sampled late October 1982 and 1984 and early November 1986 and 1990 . About $3 \mathrm{~km}^{2}$ including the exclosures were burned biennially in March 1982, 1984, 1986, 1988 (not sampled), and 1990. Gates were closed between burning in March and November 1982. Soils were classified, and longleaf pine (Pinus palustris Mill.) site index was determined (U.S. Forest Service 1976) by examining 5 sites in each replicate. Elevation was determined at each quadrat with a laser level in November 1990.

Five grazing treatments were evaluated from December 1982 to November 1990. These were: exclosures closed to grazing December to March; closed April to July; closed August to November; always open; and always closed.

Biomass data were analyzed by analysis of variance using GLM and a model for a randomized, complete block design (significance at $P<0.05$ ). Effects due to years were examined with regression analyses (SAS 1985a). Frequency of species occurrence was analyzed with the CATMOD procedure (SAS 1985b) (significance at $P<0.01$ ), which models categorical data by fitting linear models to functions of response frequencies. Effects due to years were examined with CATMOD repeated measures option. Differences in species frequency between previous years and 1990 were determined with linear contrasts. When treatment $X$ year interactions were significant, contrasts were used to make the following comparisons among treatment-year combinations for frequency of occurrence:differences between always closed and open in 1982 vs. same in 1990; differences between closed December to March and open in 1982 vs. same in 1990; differences between closed April to July and open in 1982 vs. same in 1990; differences between closed August to November and open in 1982 vs. same in 1990.

\section{Results and Discussion}

\section{Biomass}

A pooled analysis of variance using data from all 4 clipping cycles indicated that shrub and preferred grass biomass differed among treatments (Table 2). Standard deviations were quite large relative to treatment means, indicating that the experiment was sensitive only to large differences among treatments. For shrub and preferred grass biomass the year $\times$ treatment interaction was not significant $(P>0.05)$ indicating that treatment differences were consistent over years. Biomass of shrubs and preferred grasses was greater when exclosures were always closed (complete deferment) compared to all other treatments. The effect due to years was significant with shrub mass increasing quadratically and preferred grass mass increasing linearly over years in all treatments.

There were no measures of forage utilization taken 30 to 60 days after burning when most of the grazing occurred. Forage utilization was evident with greater herbage mass inside those exclosures which were closed at that time compared to the area outside of
Table 2. Mean herbage mass of various vegetational components from pooled analyses of variance over 1982, 1984, 1986, and 1990.

\begin{tabular}{|c|c|c|c|c|c|}
\hline \multirow[b]{2}{*}{ Treatment ${ }^{2}$} & \multicolumn{5}{|c|}{ Vegetation category ${ }^{1}$} \\
\hline & Shrubs ${ }^{4}$ & Wiregrass & $\begin{array}{l}\text { Other less } \\
\text { desirable } \\
\text { grasses \& } \\
\text { grasslikes }\end{array}$ & $\begin{array}{c}\text { Preferred } \\
\text { grasses }\end{array}$ & Forbs \\
\hline & - & - . - dry & matter kg hr & $-1 \ldots \ldots$ & $\ldots \ldots$ \\
\hline DJFM & $2040 b^{3}$ & $330 \mathrm{a}$ & $390 \mathrm{a}$ & $70 \mathrm{~b}$ & $160 a$ \\
\hline AMJJ & $1730 \mathrm{~b}$ & $410 a$ & $370 a$ & $70 \mathrm{~b}$ & $160 \mathrm{a}$ \\
\hline ASON & $1730 \mathrm{~b}$ & $390 \mathrm{a}$ & $370 \mathrm{a}$ & $60 \mathrm{~b}$ & $160 \mathrm{a}$ \\
\hline OPEN & $1920 \mathrm{~b}$ & $420 \mathrm{a}$ & $370 \mathrm{a}$ & $60 \mathrm{~b}$ & $180 \mathrm{a}$ \\
\hline CLOSED & $2370 a$ & $410 a$ & $320 \mathrm{a}$ & $110 \mathrm{a}$ & $150 \mathrm{a}$ \\
\hline Std. Dev. & 440 & 160 & 110 & 50 & 60 \\
\hline
\end{tabular}

ITable 1 contains plant species associated with each category.

2Months that exclosures were closed to grazing. Open and closed indicate access to grazing for the 8 year trial.

${ }_{3}$ Means in the same column followed by the same letter are not different. Duncan's Means in the same column
multiple range test $P \geq 0.05$.

YYear and treatment effects were independent for all vegetation categories. Herbage mass of shrubs and preferred grasses depended on year. Shrub $\left(\mathrm{kg} \mathrm{ha}^{-1}\right)=3040-544 \mathrm{~T}$ $+49 T^{2}$ and preferred grasses $=20+10 \mathrm{~T}$ where $\mathrm{T}=$ year -1980 .

these exclosures or between closed exclosures and adjacent ones which were open during this period.

Shrubs made up $66.4 \%$ of the total biomass, while preferred grasses made up 2.5\% (Table 2). Wiregrass constituted $13.3 \%$ of the total biomass, and other less desirable grasses and grasslikes were $12.3 \%$ of the total. All less desirable grasses and grasslikes together constituted $25.6 \%$ of biomass. Forbs made up $5.5 \%$ of the total biomass.

Herbage mass was calculated as total biomass minus shrub mass and equaled about $1,000 \mathrm{~kg} \mathrm{ha}^{-1}$ (Table 2). Our herbage estimates are similar to those obtained by Hughes (1974), who found 1,100 $\mathrm{kg} \mathrm{ha}^{-1}$ of herbaceous mass 7 months after a spring burn on the Caloosa range. At risk of predicting beyond 1990 , it would take until the year 2000 before preferred grasses would double in production from the average value $\left(110 \mathrm{~kg} \mathrm{ha}^{-1}\right)$ observed in the closed treatment $[220=20+10(X-1980)]$. This is not on a time scale relevant to management for cattle production. Our increases in preferred grass herbage mass were linear, which may not be the case over many years (Archer and Smeins 1992). We also assume that inclusion of 1988 , when herbage mass was not measured, would not change the linear model.

\section{Frequency of Occurrence}

Eighty-four plant species were found in the exclosures (Table 1). There were 15 species of shrubs, 4 species of preferred grasses, 14 species of less desirable grasses, 19 grasslike species, and 2 forb species. There was an average of 7.7 species per $0.25-\mathrm{m}^{2}$ quadrat. Since our hypothesis concerns preferred and less desirable grasses, they will be reported.

Preferred grasses The probability of finding any of 4 preferred grasses depended only on year. There was no effect due to treatment. This contrasts with previous observations and recommendations regarding flatwoods range. Hughes (1970) recommended deferred grazing for the entire growing season to increase lopsided indiangrass on range where it occurs. He also stated that excellent recovery was obtained by deferred grazing of little blue maidencane.

The percent chance of finding any preferred grass (averaged over treatments) was $43 \%$ in $1982 ; 35 \%$ in $1984 ; 45 \%$ in 1986 ; and $40 \%$ in 1990 (data not illustrated). Compared with 1990 , the probability of a difference in frequency of occurrence was: $1982, P>0.05$; 1984 , $P<0.02$; and 1986, $P<0.006$. These frequencies of occurrence are disproportionately large considering the low herbage mass of preferred grasses (Table 2). 


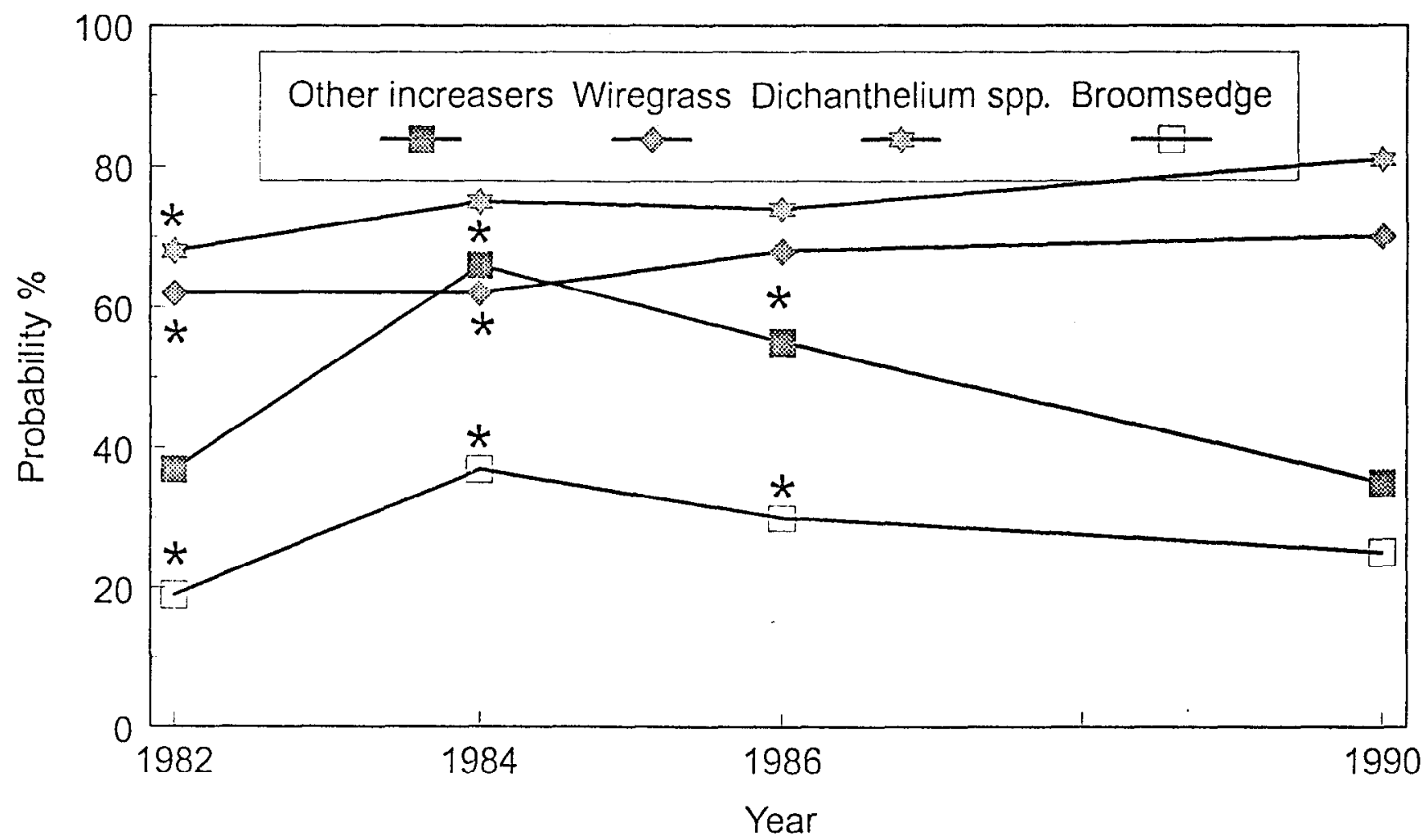

Fig. 1. Frequency of occurrence of wiregrass, Dichanthelium spp., broomsedge, or other less desirable grasses (Table 1) expressed as probability of finding these plants in $0.25 \mathrm{~m}^{3}$ quadrats from 1982 to 1990.

*Within species, year different $(P<0.01)$ compared to 1990.

Preferred grasses may not be abundant at some locations by chance. Egler (1954) and Gleason (1926) suggested that certain species were not always present in the initial composition of vegetation. However, the preferred grasses were relatively abundant on Boyd's Bay, but Boyd's Bay apparently has a limited capability for their production.

Why was the increase in herbage mass of preferred grasses so slight? Why was frequency of occurrence of these species not affected by grazing treatment? Perhaps our basic assumptions were incorrect or the range successional model was not suited to forested range (Smith 1978). Westoby et al. (1989) in their discussion of the limitations of the range successional model, cite at least 14 references where livestock had been removed from grasslands (mostly arid) and vegetation did not change or did not change in the direction predicted by the model. Other concepts explain vegetation changes on range (Laycock 1991), but none are helpful in the case of Boyd's Bay because the vegetational benchmark was based on an assumption, which may be incorrect. For example, cataloging potential range states and describing processes (transitions) that force range between states (Westoby et al. 1989) may be more realistic than an equilibrium associated with the successional model, providing a history of the states has been documented or observed. Friedel's (1991) thresholds concept is useful in cases when change has been documented and thresholds identified.

Some believe that wiregrass-dominated range is the result of uncontrolled burning and grazing, and that preferred grasses have diminished under such management (White 1973, Yarlett 1963). Because it required 2 years to accumulate suffient fuel for a burn, portions of Boyd's Bay were burned biennially and heavily grazed for about 30 to 60 days after burning. Little grazing occurred after wiregrass matured. As Hughes (1974) pointed out, low palatability in years when wiregrass range is not burned provides a natural rest, enabling wiregrass-dominant range to maintain itself.

Soils in the exclosures were typical for flatwoods range, but there were subtle differences between pedons from Boyd's Bay and pedons elswhere with the same soil classification, which may result in important differences in water-holding capacity and fertility. On a described Myakka pedon (Carlisle et al. 1985) in Hardee County, $75 \mathrm{~km}$ north, where preferred grasses are productive $(500$ to $600 \mathrm{~kg}$ $\mathrm{ha}^{-1}$ year $^{-1}$ ), there was about $10 \%$ more very fine sand and greater content of organic matter in the spodic horizon compared to Myakka pedons from Boyd's Bay (personal correspondence, $H$. Yamataki).

Soils in Boyd's Bay may be too infertile and the extremes in soil water may be too great to support high levels of preferred grass production. Slope was about $0.9 \mathrm{~m} \mathrm{~km}^{-1}$, and $100 \mathrm{~mm}$ above or below mean elevation for a given exclosure included $93 \%$ of the observations made within that 1-ha exclosure. During the June to September rainy season Boyd's Bay has surface water over most of the area, while in the dry season, plants are subjected to extremely dry soil. The average environment may be near optimum for some species (i.e., wiregrass) and near physiological limits for others (i.e., preferred grasses) (Gleason 1926).

Tree site index ranged from 13.8 to 18.3 and averaged 16.2 in Boyd's Bay, which means that in 50 years these longleaf pines would be expected to attain a height of $16.2 \mathrm{~m}$. Boyd's Bay had a low index compared to much of south Florida where indices of 18.3 to 24.5 are common. The relatively poor site index on Boyd's Bay indicates that the site has more than average limitations. Tree site index could be a better predictor of herbage production on forested range than soil classification if relationships between tree site index and herbage mass were developed.

On widely isolated spots, where an old tree had decayed or where a stump had been removed, thus bringing a more fertile spodic horizon to the surface, dense stands of creeping bluestem established. Perhaps with establishment of pine stands, which was observed to be occurring in Boyd's Bay, a threshold will be approached where responses by herbaceous plants can be obtained 
with appropriate grazing management.

Grouping grasses into preferred or less desirable classifications according to palatability and production potential and using these designations to determine flatwoods range condition has value for ranchers in that it provides a basis for practical decisions such as carrying capacity. The problem arises when it is assumed that all range with low proportions of preferred species can be improved i.e., produce more of the preferred grasses by following proper grazing management. Range improvement implies that deterioration has taken place, which may not be the case for Boyd's Bay.

Less desirable grasses Year $X$ treatment interactions were significant for each of the categories discussed below. When treatmentyear combinations were plotted, it could be seen that interactions in frequency of occurrence were due to anomalies in 1 or more treatments in 1 year. There was little effect due to treatment, while effects due to years were large and will be discussed.

The most abundant plants on the study area, Dichanthelium spp, increased $(P<0.01)$ in frequency of occurrence between 1982 and 1986 (Fig. 1). Wiregrass frequency of occurrence increased $(P<0.01) 8$ percentage units from 1982 to 1990 . Broomsedge was the third most frequently found of the less desirable grasses. Frequency of occurrence of both broomsedge (and other less desirable grasses) fluctuated greatly over years. Broomsedge increased $(P<0.01) 18$ percentage units between 1982 and 1984 , then declined 12 percentage units over the following 4 years. Other less desirable grasses increased $(P<0.01) 29$ percentage units between 1982 and 1984 then declined 31 percentage units over the next 4 years.

\section{Conclusions}

The frequently burned, seasonally flooded, highly infertile wiregrass-dominated range at Boyd's Bay was not highly responsive to grazing or deferment from grazing. Past recommendations for optimizing livestock responses to wiregrass range by frequent burning to enhance quality and acceptability of herbage appear to be appropriate. Recommendations, which were at least partially based on results from more fertile sites, to defer grazing to produce increases in stands of the preferred grasses are not likely to produce the desired effects on sites like Boyd's Bay. Even with no grazing for 8 years, the preferred grasses did not increase substantially. Under present conditions with such infertile soils, responses by herbaceous plants to grazing management on wiregrass-dominant range may not be sufficient to justify the inputs.

The validity of the concept of a threshold to be overcome, in this case by development of forest soil conditions with increased fertility, organic matter, and water holding capacity, before a transition or change in composition of herbaceous plants can occur needs to be evaluated. Documentation of such conditions, should they exist, could greatly enhance opportunities for efficiently managing and improving these rangelands. However, the possibility that a potential natural community on some south Florida flatwoods may be pine forest with very low proportions of preferred grasses for livestock grazing must also be considered.

\section{Literature Cited}

Archer, S., and F.E. Smeins. 1992. Non-linear dynamics in grazed ecosystems: thresholds, multiple steady states and positive feedbacks. p. 4-6 In: T. Svejcar and J. Brown (eds.) Is the Range Condition and Trend Concept Compatible with Ecosystem Dynamics? Soc. Range Manage. Denver, Colo.

Carlisle, V.W., M.E. Collins, F. Sodek, III, and L.C. Hammond. 1985. Characterization data for selected Florida Soils. Soil Sci. Res. Rep. 85-1. Univ. Florida-IFAS. Gainesville.

Egler, F.E. 1954. Vegetation science concepts: 1. Initial floristic composition, a factor in old-field development. Vegetatio 4:412-417.

Friedel, M.H. 1991. Range condition assessment and the concept of thresholds: A viewpoint. J. Range Manage. 44:422-426.

Gleason, H.S. 1926. The individualistic concept of plant association. Bull. Torrey Bot. Club. 53:7-26.

Hilmon, J.B. 1964. Plants of the Caloosa Range. USDA Forest Serv. Res. Pap. SE-12. Asheville, N.C.

Hughes, R.H. 1970. Year-long management of forage and cattle on pinewiregrass ranges of the southeastern United States. Proc. 11th Int. Grassl. Congr.: 45-48.

Hughes, R.H. 1974. Management and utilization of pineland threeawn range in south Florida. J. Range Manage. 27:186-192.

Kirk, W.G., and E.M. Hodges. 1970. Effect of controlled burning on production of cows on native range. Soil Crop Sci. Soc. Fla. Proc. 30:341-343.

Laycock, W.A. 1991. Stable states and thresholds of range condition on North American rangelands: a viewpoint. J. Range Manage. 44:427-433.

Lewis, C.E., H.E. Grelen, and G.E. Probasco. 1982. Prescribed burning in southern forest and rangeland improves forage and its use. Southern J. Applied Forestry 6:19-25.

Prevatt, J.W., R.G. Hendricks, G.W. Tanner, and R.S. Kalmbacher. 1985. An economic evaluation of range management practices. Soil Crop Sci. Soc. Fla. Proc. 44:184-186.

SAS Institute, Inc. 1985a. SAS/STAT Guide for personal computers. Version 6 Edition. Cary, N.C.

SAS Institute, Inc. 1985b. SAS users guide: Statistics. Version 5 Edition. Cary, N.C.

SCS. 1987. Range management for important native grasses of Florida. USDA Soil Conserv. Serv. Gainesville, Fla.

Smith, E.L. 1978. A critical evaluation of the range condition concept. p. 226-227. In: D.N. Hyder (ed.) Proc. Ist Int. Rangeland Congr. Soc. Range Manage. Denver, Colo.

U.S. Forest Service. 1976. Volume, yield, and stand tables for secondgrowth southern pines. USDA Forest Serv. Misc. Pub. 50. Washington, D.C.

Westoby, M.B., B. Walker, and I. Noy-Meir. 1989. Opportunistic management for rangelands not at equilibrium. J. Range Manage. 42:266-274.

White, L.D. 1973. Native forage resources and their potential. In: R.S. Campbell and W. Keller (eds.) Range resources of the southestern United States. ASA Spec. Pub. 21. Amer. Soc. Agron. Madison, Wis.

Wunderlin, R.P. 1982. Guide to the vascular plants of central Florida. Univ. Presses of Florida, Gainesville.

Yarlett, L.L. 1963. Some important and associated native grasses on central and south Florida range. J. Range Manage. 16:25-27. 